\title{
Characterization of Streptomyces Isolates Associated with Estuarine Fish Chanos chanos and Profiling of Their Antibacterial Metabolites-Crude-Extract
}

\author{
Muhammad A. Kurnianto, ${ }^{1}$ Harsi D. Kusumaningrum $\mathbb{D}^{\circ},{ }^{2}$ and Hanifah N. Lioe ${ }^{2}$ \\ ${ }^{1}$ Food Science Study Program, Graduate School, IPB University, Bogor, Indonesia \\ ${ }^{2}$ Department of Food Science and Technology, Faculty of Agricultural Engineering and Technology, IPB University, \\ Bogor, Indonesia
}

Correspondence should be addressed to Harsi D. Kusumaningrum; h_kusumaningrum@apps.ipb.ac.id

Received 22 June 2020; Accepted 12 September 2020; Published 23 September 2020

Academic Editor: Giuseppe Comi

Copyright (c) 2020 Muhammad A. Kurnianto et al. This is an open access article distributed under the Creative Commons Attribution License, which permits unrestricted use, distribution, and reproduction in any medium, provided the original work is properly cited.

\begin{abstract}
Streptomyces has been reported as an essential producer of bioactive substances, including antibiotics and other types of antimicrobials. This study investigated antibacterial-producing Streptomyces isolated from the gut of estuarine fish Chanos chanos, emphasizing screening for the producer of peptide-containing antibacterial compounds. Eighteen isolates were found during preliminary screening, in which four isolates showed the best antibacterial activities. Based on the morphological, physiological, and biochemical characterization, as well as 16S rRNA partial sequencing, all of the four isolates belonged to Streptomyces. Three isolates were suspected as novel isolate candidates based on homology presentations and phylogenetic tree analysis. Disk-diffusion assay of the metabolite-crude-extract from the isolates showed broad-spectrum inhibitory activities against Staphylococcus aureus ATCC 25923, Bacillus cereus ATCC 10876, Escherichia coli ATCC 25922, and Pseudomonas aeruginosa InaCC B52 with minimum inhibitory concentration and minimum bactericidal concentration ranging from $2.5-10 \mathrm{mg} / \mathrm{mL}$ and $5-10 \mathrm{mg} / \mathrm{mL}$, respectively. The highest antibacterial activity with low MIC and MBC values was shown by isolate AIA-10. Qualitative HPLC profiling revealed that the metabolic-crude-extracts showed many peaks with intensive area at 210 and $214 \mathrm{~nm}$, especially from SCA-11 and AIA-10, indicating the presence of peptide groups in the structure of the constituent compound. The results also suggested that crude extracts SCA-11 and AIA-10 had higher hydrophobicity properties than the other extracts. Further characterization of the active compound was needed to find out which compounds were responsible for the antibacterial activity. The results of this study indicated that some Streptomyces isolated from new environmental niches, i.e., gut of estuarine fish Chanos chanos, produce promising peptide-containing bioactive compounds.
\end{abstract}

\section{Introduction}

Streptomyces is one of the organisms with a complex life cycle that has been widely explored in its ability to produce bioactive compounds [1]. In general, Streptomyces are considered as free-living bacteria and are commonly found in terrestrial ecosystems. However, researchers' increased focus on these bacteria revealed that they could associate or form a symbiosis with eukaryotic hosts and have the most extensive relative abundance throughout the ecosystem [2-5]. This reflects their physiological ability and gives reciprocal effects of evolution that affect the growth, reproduction, and capacity of bacteria to produce a variety of secondary metabolites [6-8]. This condition provides an excellent reason to promote research in this emerging area [3].

Estuarine is one of the aquatic ecosystems of Streptomyces habitat that is rarely explored. In this ecosystem, there is conflux between the saltwater from sea and freshwater from rivers that causes continual change in salinity levels and persistent tidal gradients [9-11]. This condition also makes the estuary rich in organic material that can support 
the growth of various communities of the microorganism [12]. But, on the other hand, it also triggers competition between organisms over nutrition and encourages some organisms, such as bacteria, to produce secondary metabolites as a defence response [13]. Adaptation in this competition encourages the formation of special physiological and metabolic abilities that enable them to produce different types of secondary metabolites that cannot be produced by bacteria living in normal conditions [14].

The most intriguing and widely explored characteristic of Streptomyces is its ability to produce bioactive secondary metabolites with antimicrobial activity, one of which is peptide-containing antibacterial $[1,15,16]$. Peptides become one of the structural classes of antimicrobials produced from ribosomes or nonribosomes [16]. The ribosomally synthesized and post-translationally modified peptides (RiPPs) are a large class of natural products introduced by post-translational modifications with a high degree of structural diversity and a wide variety of bioactivities that are poorly understood [16, 17]. Some RiPPs which are produced by Streptomyces have been reported, such as siamycin-I by Streptomyces sp. [18], cinnamycin by S. cinnamoneus [19], bottromycin by $S$. bottropensis [20], bacteriocin-like by S. scopuliridis [21], grisemycin by S. griseus [22], telomestatin by $S$. anulatus [23], and archromosin by $S$. achromogenes [24].

A preliminary study by Kurnianto et al. [25] reported isolation of 22 Actinobacteria isolates from estuarine milkfish (Chanos chanos) and blue-spot mullet fish (Mugil cephalus) based on their inhibitory index against four test bacteria. This study investigated selected Streptomyces isolates associated with milkfish Chanos chanos that possibly produce peptide-containing metabolite with potential antibacterial activity. This metabolite was explored to look for possible uses in food in the future. HPLC profiling of the metabolite-crude-extract was carried out to figure out the spectra of the target group.

\section{Materials and Methods}

2.1. Preliminary Screening of Potent Isolates as Antibacterial Producers. Twenty-eight presumptive Streptomyces isolates from the milkfish gut from the previous study [25] were purified, regrown on yeast-malt extract agar (ISP-2 agar; yeast extract $4 \mathrm{~g}$, malt extract $10 \mathrm{~g}$, dextrose broth $4 \mathrm{~g}$, bacteriological agar $20 \mathrm{~g}$, and distilled water $1000 \mathrm{~mL}$ ), and incubated for $10-14$ days at $30^{\circ} \mathrm{C}$. The isolates were, then, screened qualitatively based on their inhibition zone using cross streak and, later, quantitatively by the double-layer diffusion method against pathogenic bacteria. Four different bacteria were used as indicators, i.e., Gram-positive (Bacillus cereus ATCC 10876 and Staphylococcus aureus ATCC 25922) and Gram-negative (Escherichia coli ATCC 25922 and Pseudomonas aeruginosa InaCC B52). In the crossstreak method, a Mueller-Hinton agar (Oxoid, UK) plate was scratched with the isolate in the center of the plate and incubated for 7 days at $30^{\circ} \mathrm{C}$. The indicators were, then, scratched perpendicular to the first scratch and incubated at $37^{\circ} \mathrm{C}$ overnight [26]. In the double-layer diffusion method, the isolates that had been grown for seven days on ISP-2 agar were cut using a cork borer ( $6 \mathrm{~mm}$ diameter) and placed in a plate containing two-layers of nutrient agar (NA; Oxoid, UK), which had been inoculated with indicators on the top layer. The bottom layer was NA with a single-strength concentration (28 g NA in $1000 \mathrm{~mL}$ destination water), and the top layer was NA with a half-strength concentration (14 g $\mathrm{NA}$ in $100 \mathrm{~mL}$ distillation water). Plates were incubated at $37^{\circ} \mathrm{C}$ overnight [27]. Isolates with the best inhibitory activity against indicators were selected for further analysis.

\subsection{Molecular Characterization Using 16S rRNA Partial} Sequencing. The presumptive Streptomyces isolates were grown in yeast-malt extract broth (ISP-2 broth; yeast extract: $4 \mathrm{~g}$, malt extract: $10 \mathrm{~g}$, dextrose: $4 \mathrm{~g}$, and distilled water $1000 \mathrm{~mL}$ ) for 7 days at $30^{\circ} \mathrm{C}$. The culture media were, then, centrifuged (Hermle, Germany) at 10,000 rpm for $15 \mathrm{~min}$ utes to obtain cell biomass (mycelia) used for DNA extraction processes [28]. Furthermore, the 16S ribosomal RNA gene was amplified by PCR using 9F (5'-GAGTTTGATCCTGGCTCAG) and 1541R (5'-AAGGAGGTGATCCAGCC) primers [29]. The product amplified by PCR was qualitatively evaluated by electrophoresis $1 \%(\mathrm{w} / \mathrm{v})$, and then, it was sequenced. The sequenced data were converted to the FASTA format and analyzed using the BLAST program to identify homology and obtain similar isolates that are closely related based on the database of NCBI (http:// www.ncbi.nlm.nih.gov). FASTA files from presumptive Streptomyces and similar closely related isolates were aligned using ClustalX, and their phylogenetic trees were analyzed using MEGA 6 with Neighbor-Joining (NJ) algorithm with 1000 bootstrap resampling [30].

2.3. Morphological, Cultural, Physiological, and Biochemical Characterization. Macroscopic morphology was studied by inoculating isolates on four different media, i.e., starch casein agar (SCA; Starch $10 \mathrm{~g}, \mathrm{~K}_{2} \mathrm{HPO}_{4} 2 \mathrm{~g}, \mathrm{KNO}_{3} 2 \mathrm{~g}$, casein $0.3 \mathrm{~g}, \mathrm{MgSO}_{4} .7 \mathrm{H}_{2} \mathrm{O} 0.05 \mathrm{~g}, \mathrm{CaCO}_{3} 0.02 \mathrm{~g}, \mathrm{FeSO}_{4} .7 \mathrm{H}_{2} \mathrm{O}$ $0.01 \mathrm{~g}$, bacteriological agar $15 \mathrm{~g}$, and distilled water $1000 \mathrm{~mL}$ ), yeast-malt agar (ISP-2 agar), tryptone-yeast agar extract (ISP-1; tryptone $5 \mathrm{~g}$, yeast extract $3 \mathrm{~g}$, and distilled water $1000 \mathrm{~mL}$ ), and inorganic salts-starch agar (ISP-4; $\mathrm{K}_{2} \mathrm{HPO}_{4} 1 \mathrm{~g}, \mathrm{MgSO}_{4} .7 \mathrm{H}_{2} \mathrm{O} 1 \mathrm{~g}, \mathrm{NaCl} 1 \mathrm{~g},\left(\mathrm{NH}_{4}\right)_{2} \mathrm{SO}_{4} 2 \mathrm{~g}$, $\mathrm{CaCO}_{3} 2 \mathrm{~g}$, trace salts solution $1.0 \mathrm{~mL}$, and distilled water $500 \mathrm{~mL}$ ). After incubation, three characteristics were observed, i.e., pigment production, aerial mycelium, and substrate mycelium [26]. Microscopic morphology was studied using the coverslip method by which spore-bearing hyphae morphology with the entire spore chain was observed under a light microscope (Nikon, Japan) as described by Shirling and Gottlieb [31]. The utilization of carbohydrate sources was determined by growing each isolate on media that were supplemented with carbon sources at a concentration of $1 \%$ [32]. The ability of isolates to tolerate $\mathrm{pH}$ and $\mathrm{NaCl}$ was determined by inoculating isolates in an inorganic salt-starch agar medium (ISP-4) conditioned at a $\mathrm{pH}$ range of $5-10$ and $\mathrm{NaCl}$ concentrations of $2-6 \%$ [33]. The ability of isolates to produce hemolysin, which can break down red 
blood cells, was determined by inoculating the isolates on sheep blood agar [34]. The ability to produce specific enzymes and other biochemical tests was evaluated using the API 20 kit (Biomerieux, France) [35, 36]. All results were collected after 7 days of incubation at $30^{\circ} \mathrm{C}$.

\subsection{Determination of the Optimum Production Medium and} Production of the Metabolite-Crude-Extract. The determination of the optimum production medium was conducted by culturing the isolates on three different media: yeast-malt extract broth (ISP-2 broth), nutrient broth glucose (NBG; nutrient broth $13 \mathrm{~g}$, glucose $4 \mathrm{~g}$, and distilled water $1000 \mathrm{~mL}$ ), and Gause synthetic broth (GSB; starch $20 \mathrm{~g}, \mathrm{NaCl} 0.5 \mathrm{~g}$, $\mathrm{FeSO}_{4} \cdot \mathrm{H}_{2} \mathrm{O} 0.01 \mathrm{~g}, \mathrm{KNO}_{3} 1 \mathrm{~g}, \mathrm{~K}_{2} \mathrm{HPO}_{4} 0.5 \mathrm{~g}, \mathrm{MgSO}_{4} 0.5 \mathrm{~g}$, and distilled water $1000 \mathrm{~mL}$ ). The culture media were incubated for 10 days at $30^{\circ} \mathrm{C}$ and, then, centrifuged (Hermle, Germany) at $8000 \mathrm{rpm}$ for 15 minutes to separate the supernatant and biomass. The supernatant was evaluated for antibacterial activity by the microdilution method [37], against Staphylococcus aureus ATCC 25922 and Escherichia coli ATCC 25922. Optimum production media were determined by the better ability of the culture supernatant to inhibit the growth of test bacteria. The lower optical density (OD) found in the microdilution test indicated the higher inhibitory activity. The dry weight of the cell biomass and antibacterial activity, starting on the 3rd day until the 11th day (every 48-hours interval), were also measured to determine the growth phase of bacteria and the optimum antibacterial production time [14, 37].

The metabolite production was carried out by inoculating the isolates on the best growth media for optimum incubation period in a shaker incubator (New Brunchwick, Germany) at $120 \mathrm{rpm}$ at $30^{\circ} \mathrm{C}$. The bacterial culture was centrifuged (Hermle, Germany) at $8000 \mathrm{rpm}$ for 15 minutes. Cell-free supernatants obtained were, then, mixed with ethyl acetate (Merck, Germany) 1:1 (v/v) followed by the extraction with a separating funnel and evaporated using a rotary vacuum evaporator (Buchi, Switzerland) at $45^{\circ} \mathrm{C}$ to obtain the metabolite-crude-extract. The dried metabolitecrude-extract was dissolved in DMSO (Merck, Germany), and a stock concentration was prepared of about $10 \mathrm{mg} / \mathrm{mL}$ $[26,38]$.

\subsection{Antibacterial Activity Test and Determination of the} Minimum Inhibitory Concentration (MIC) and Minimum Bactericidal Concentration $(M B C)$. A sterile disc $(6 \mathrm{~mm}$ diameter; Oxoid, UK) was dripped with $20 \mu \mathrm{L}$ of the metabolite-crude-extract, placed on the surface of the MuellerHinton Agar (MHA; Oxoid, UK) that has been rubbed with a cotton swab containing test bacteria, and then, incubated for 24 hours at $37^{\circ} \mathrm{C}$. The antibacterial activity was, then, assessed by measuring the inhibition zone diameter $(\mathrm{mm})$ on agar [39]. The determination of MIC values of the metabolite-crude-extract was performed by the microdilution method. The metabolite-crude-extracts with a concentration of $10,5.0,2.5,1.25,0.625,0.312$, and $0.156 \mathrm{mg} / \mathrm{mL}$ were added to microtiter plate which contained $0.1 \mathrm{~mL}$ MuellerHinton Broth (MHB; Himedia, India). An amount of $0.1 \mathrm{~mL}$ of the test bacteria was pipetted into each well, to obtain a final inoculum density obtained of approximately $1 \times 10^{6} \mathrm{CFU} / \mathrm{mL}$. Afterward, the microtiter plate was incubated for 24 hours at $37^{\circ} \mathrm{C}$. The minimum bactericidal concentration $(\mathrm{MBC})$ was determined by taking a small amount of mixed liquid in a microtiter plate from the MIC test results with a loop, then scratched on Mueller-Hinton Agar (MHA; Himedia, India), and incubated for 24 hours at $37^{\circ} \mathrm{C}$. All analyses used ampicillin (Oxoid, UK) as a positive control and DMSO (Merck, Germany) as the negative control [40].

2.6. Profiling of the Metabolite-Crude-Extract Using HPLC. The metabolite-crude-extract was dissolved in methanol ( $1 \mathrm{mg} / \mathrm{mL}$; Merck, Germany) and, then, analyzed by using the Agilent 1200 Series HPLC using the $4.60 \times 150 \mathrm{~mm}$ $(5 \mu \mathrm{m})$ Zorbax eclipse XDC-C18 column. The HPLC system used an elution with a gradient mobile phase (A acetonitrile (Merck, Germany), B water; 0-30 min 10\% A-50\% B). The sample was run in 30 minutes at a flow rate of $0.5 \mathrm{~mL} / \mathrm{min}$. The compounds present were detected using a multiwavelength UV-Vis detector (MWD) at 210, 214, 254, and $276 \mathrm{~nm}$ [41].

\section{Results}

3.1. Potential Isolates as Antibacterial Producers. The morphological appearance of some purified isolates on ISP-2 agar is shown in Figure 1. Most of the isolates showed characteristics such as a white-colored colony surface and a dry and powdered texture, and some colonies were able to produce pigments.

Preliminary screening using the cross-streak method indicated that 23 of 28 isolates showed inhibitory activity against, at least, one indicator. Meanwhile, the evaluation using a double-layer diffusion agar method showed only 18 isolates which had inhibitory activity (Table 1). Out of them, four isolates (SCA-5, SCA-8, AIA-10, and SCA-11) exhibited potential inhibitory activity against all indicators.

3.2. Characteristics of Selected Streptomyces Isolates. The molecular characterization based on 16S rRNA partial sequencing indicated that all isolates were Streptomyces (Table 2). Isolate SCA-11 showed maximum $16 \mathrm{~S}$ rRNA gene sequence homology (100\%) with Streptomyces variabilis strain 34-HR0-O, T4, and AHS2. However, other three isolates (SCA-5, SCA-8, and AIA-10) showed 16S rRNA gene sequence homology below $98 \%$, in which SCA-5 and AIA-10 were homologous to Streptomyces variabilis strain HBUM173496 and SCA-8 was homologous to Streptomyces labedae strain $\mathrm{RD} 16$. The phylogenetic analysis results also showed that the three isolates were separated from their closest strains. The phylogenetic tree construction is shown in Figure 2.

Morphological characterization showed that all isolates were Gram-positive filamentous bacteria. Morphological characterization on four different media showed an efficient growth on ISP-2 media (Table 3). On these media, the four 

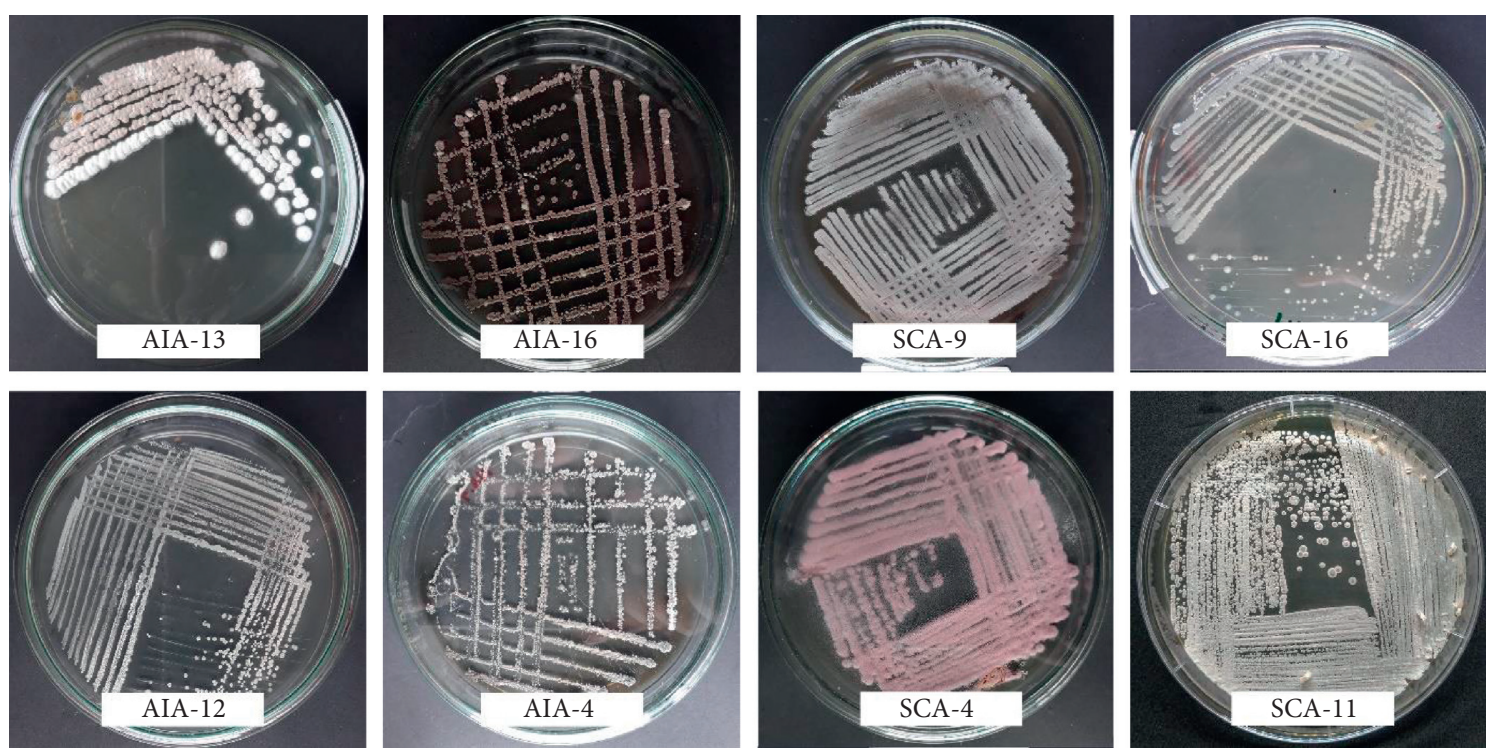

FIGURE 1: Morphological diversity of presumptive Streptomyces isolates in yeast-malt extract agar (ISP-2 agar).

selected isolates formed aerial mycelium with white to grey colour and substrate mycelium with white to brown colour. One of the isolates, SCA-8, showed the ability to produce light-yellow pigments that were resulted from the colour changes in the growth media.

The sporophore morphology observation by a light microscopic analysis showed that the isolates had retinaculiaperti, rectus-flexibilis, and spira spore chain types (Figure 3).

The microscopy morphological, physiological, and biochemical characteristics of the selected isolates are presented in Table 4. Tolerance tests on $\mathrm{pH}$ and $\mathrm{NaCl}$ showed that all isolates were able to grow well at $\mathrm{pH} 6$ to 9 , with $\mathrm{NaCl}$ concentrations reaching $6 \%$. The majority of isolates were also able to utilize carbon sources such as sucrose, glucose, amygdalin, and arabinose and were able to produce urease and hydrogen sulphide.

3.3. Optimum Production Medium. The determination of antibacterial production media was carried out to determine the best medium for growth and to maximize the production of antibacterial compounds. The results showed ISP-2 as the best production medium. The inhibitory activity test using the microdilution method showed that exposure to the ISP-2 supernatant resulted in lower optical density (OD) than exposure to other media supernatants. Statistical analysis also showed a significant difference in OD E. coli exposed to the ISP-2 supernatant compared to OD E. coli exposed to other media supernatants (all supernatant isolates). Different results were obtained for $S$. aureus, which was only in the supernatant exposure of ISP-2 from SCA-11 and SCA-8 isolates which had significantly different OD values (Figure 4).

The growth curves based on the dry weight of cell biomass of all isolates that were produced in ISP-2 broth (selected optimum media) are shown in Figure 5. Three isolates (SCA-5, SCA-11, and AIA-10) started their logarithmic phase within the 5th day after inoculation. This phase generally continued until the 9th day, and after that, the stationary phase occurred. Different from the other three isolates, SCA-8 started the logarithmic phase at the 7th day, continued until the 9th day, and then, proceeded to the stationary phase. Based on the microdilution test of the cellfree supernatant, all isolates likely started to produce metabolites that were able to inhibit the growth of test bacteria after the 5th day of incubation. The inhibitory activity continued to increase until the 9th day or after proceeding to the stationary phase (data not shown).

\subsection{Antibacterial Activity of the Metabolite-Crude-Extract.} All metabolite-crude-extracts produced by selected isolates showed the promising result of antibacterial activity. The highest antibacterial activity was demonstrated by the AIA10 crude extract with the highest inhibitory zone of $22.2 \mathrm{~mm}$ against $S$. aureus and $21.3 \mathrm{~mm}$ against $P$. aeruginosa. The antibacterial activity of AIA-10 was significantly higher compared to the other metabolite-crude-extracts (Table 5).

The MIC values of the metabolite-crude-extract of all test bacteria ranged from 2.5 to $10 \mathrm{mg} / \mathrm{mL}$. Meanwhile, the $\mathrm{MBC}$ values ranged from 5 to $10 \mathrm{mg} / \mathrm{mL}$ (Table 6). The highest MIC and MBC were exhibited by AIA-10 and SCA-11 with values of $2.5 \mathrm{mg} / \mathrm{mL}$ and $5 \mathrm{mg} / \mathrm{mL}$, respectively. These results showed that the MBC value of all metabolite-crudeextracts was two times higher than the MIC value, except for SCA-8.

3.5. HPLC Metabolite-Crude-Extract Profile. The chromatogram profile of all metabolite-crude extracts exhibited many peaks detected during a retention time of $0-30$ minutes. Qualitatively, the metabolite-crude-extracts showed similar trends at 210 with $214 \mathrm{~nm}$ and 254 with $276 \mathrm{~nm}$. At 210 and $214 \mathrm{~nm}, 10$ peaks, 11 peaks, 9 peaks, and 9 peaks were detected on the chromatogram of SCA-11, 
TABle 1: Preliminary screening using cross streak and evaluation of antibacterial activity using double-layer agar diffusion.

\begin{tabular}{|c|c|c|c|c|c|c|c|c|}
\hline \multirow{3}{*}{ Isolates } & \multicolumn{8}{|c|}{ Inhibition zone $(\mathrm{mm})$} \\
\hline & \multicolumn{2}{|c|}{ S. aureus } & \multicolumn{2}{|c|}{ B. cereus } & \multicolumn{2}{|c|}{ E. coli } & \multicolumn{2}{|c|}{ P. aeruginosa } \\
\hline & $\begin{array}{l}\text { Cross } \\
\text { streak }\end{array}$ & $\begin{array}{c}\text { Double-layer } \\
\text { agar }\end{array}$ & $\begin{array}{l}\text { Cross } \\
\text { streak }\end{array}$ & $\begin{array}{c}\text { Double-layer } \\
\text { agar }\end{array}$ & $\begin{array}{l}\text { Cross } \\
\text { streak }\end{array}$ & $\begin{array}{c}\text { Double-layer } \\
\text { agar }\end{array}$ & $\begin{array}{l}\text { Cross } \\
\text { streak }\end{array}$ & $\begin{array}{c}\text { Double-layer } \\
\text { agar }\end{array}$ \\
\hline SCA-7 & - & - & +++ & $12.9 \pm 0.47$ & - & - & - & - \\
\hline SCA-6 & ++ & $11.6 \pm 0.72$ & - & - & - & - & - & - \\
\hline $\begin{array}{l}\text { SCA- } \\
13\end{array}$ & +++ & $14.6 \pm 0.70$ & ++ & - & - & - & - & - \\
\hline AIA-1 & - & - & ++ & - & - & - & - & - \\
\hline AIA-6 & - & - & ++ & - & - & - & - & - \\
\hline AIA-5 & + & - & - & - & - & - & - & - \\
\hline SCA-4 & - & - & ++ & - & + & - & - & - \\
\hline $\begin{array}{l}\text { SCA- } \\
10\end{array}$ & - & $17.9 \pm 0.50$ & - & - & - & - & - & - \\
\hline SCA-9 & - & $20.6 \pm 0.37$ & - & - & ++ & - & + & - \\
\hline SCA-5 & +++ & $19.5 \pm 0.32$ & +++ & 10. $9 \pm 0.28$ & ++ & $13.5 \pm 0.83$ & + & - \\
\hline $\begin{array}{l}\text { SCA- } \\
11\end{array}$ & +++ & $20.6 \pm 0.53$ & +++ & $9.8 \pm 0.09$ & +++ & $14.9 \pm 0.63$ & ++ & $10.3 \pm 0.64$ \\
\hline AIA-12 & +++ & $16.3 \pm 0.77$ & +++ & - & ++ & - & - & - \\
\hline AIA-13 & - & $13.8 \pm 0.49$ & +++ & $9.5 \pm 0.06$ & - & - & - & - \\
\hline $\begin{array}{l}\text { SCA- } \\
12\end{array}$ & + & $10.6 \pm 0.49$ & + & - & ++ & - & - & - \\
\hline AIA-10 & +++ & $21.4 \pm 1.47$ & ++ & $14.3 \pm 0.62$ & +++ & $13.3 \pm 1.04$ & + & - \\
\hline AIA-9 & - & $13.0 \pm 0.11$ & - & - & - & - & - & - \\
\hline AIA-15 & - & - & + & - & - & - & - & - \\
\hline AIA-16 & - & $14.2 \pm 0.09$ & ++ & - & + & - & - & - \\
\hline SCA-8 & +++ & $18.8 \pm 0.14$ & ++ & $12.2 \pm 0.40$ & ++ & $16.3 \pm 1.24$ & + & - \\
\hline AIA-17 & ++ & $18.7 \pm 0.24$ & ++ & - & ++ & $8.6 \pm 0.47$ & - & - \\
\hline $\begin{array}{l}\text { SCA- } \\
16\end{array}$ & - & - & - & - & - & - & + & - \\
\hline $\begin{array}{l}\text { SCA- } \\
17\end{array}$ & - & - & - & - & - & - & ++ & - \\
\hline $\begin{array}{l}\text { SCA- } \\
18\end{array}$ & - & $9.9 \pm 0.57$ & - & - & - & - & - & - \\
\hline $\begin{array}{l}\text { SCA- } \\
19\end{array}$ & - & $13.5 \pm 1.61$ & - & - & - & - & - & - \\
\hline $\begin{array}{l}\text { SCA- } \\
20\end{array}$ & + & - & - & - & - & - & - & - \\
\hline SCA-21 & - & - & + & - & - & - & - & - \\
\hline $\begin{array}{l}\text { SCA- } \\
22\end{array}$ & - & $15.9 \pm 0.29$ & - & $9.4 \pm 0.26$ & - & - & - & - \\
\hline $\begin{array}{l}\text { SCA- } \\
23\end{array}$ & - & - & + & - & - & - & - & - \\
\hline
\end{tabular}

(-): no inhibition; (+): weak inhibition; (++): moderate inhibition; (+++): good inhibition; value was mean \pm SD (standard deviation) from three replication; $(-)$ : no zone of inhibition.

TABLE 2: The results of gene sequence alignments of $16 \mathrm{~S}$ rRNA selected Streptomyces isolates to data available at NCBI (BLASTN).

\begin{tabular}{|c|c|c|c|c|c|c|c|}
\hline Isolates & $\begin{array}{c}\text { BLAST result (16S ribosomal RNA gene, partial } \\
\text { sequence) }\end{array}$ & $\begin{array}{l}\text { Max } \\
\text { score }\end{array}$ & $\begin{array}{l}\text { Total } \\
\text { score }\end{array}$ & $\begin{array}{l}\text { Query cover } \\
(\%)\end{array}$ & E value & $\begin{array}{c}\text { Ident } \\
(\%)\end{array}$ & Accession \\
\hline SCA-5 & Streptomyces variabilis strain HBUM173496 & 942 & 942 & 99 & 0 & 93.92 & EU841661.1 \\
\hline \multirow{2}{*}{ SCA-8 } & Streptomyces labedae strain RD16 & 652 & 652 & 99 & 0 & 95.37 & KY378908.1 \\
\hline & Streptomyces variabilis strain $34-\mathrm{HR} 0-\mathrm{O}$ & 1454 & 1454 & 100 & 0 & 100 & MF077022.1 \\
\hline SCA- & Streptomyces variabilis strain $\mathrm{T} 14$ & 1454 & 1454 & 100 & 0 & 100 & KY213667.1 \\
\hline \multirow[t]{2}{*}{11} & Streptomyces variabilis strain AHS2 & 1454 & 1454 & 100 & 0 & 100 & KU981101.1 \\
\hline & Streptomyces labedae strain CTF14 & 1454 & 1454 & 100 & 0 & 100 & EU294135.1 \\
\hline AIA-10 & Streptomyces variabilis strain HBUM173496 & 1070 & 1070 & 99 & 0 & 92.01 & EU841661.1 \\
\hline
\end{tabular}




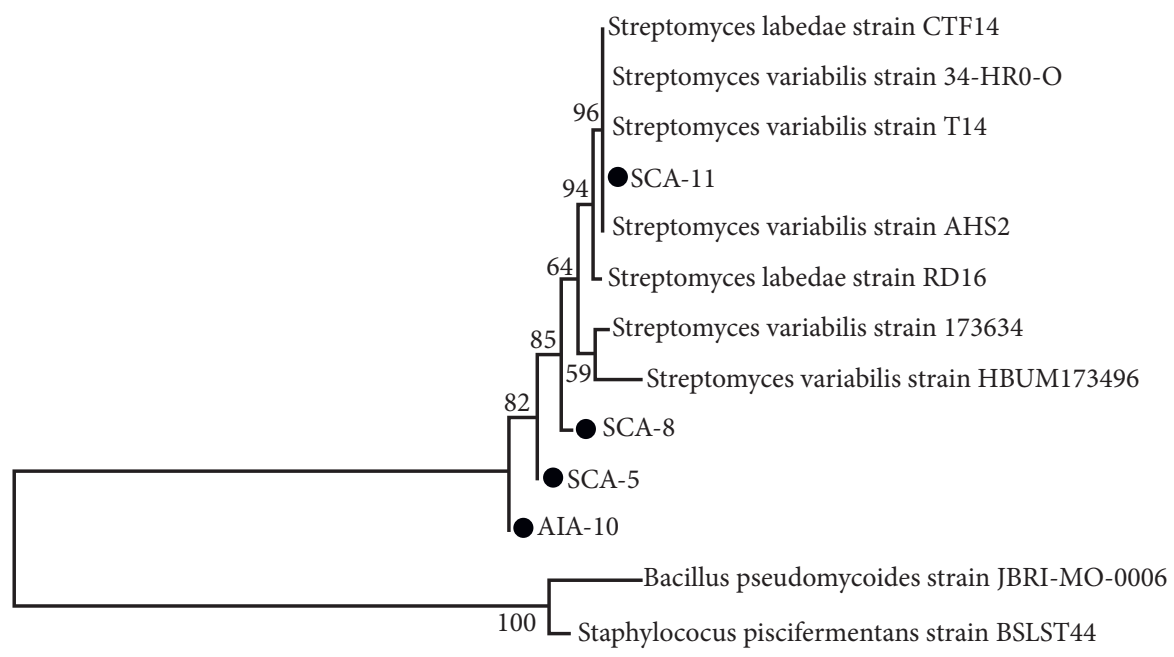

FIGURE 2: Phylogenetic tree of SCA-5, SCA-8, SCA-11, and AIA-10 constructed with the aid of MEGA 6.0 program.

TABLE 3: Morphological characteristics of selected Streptomyces isolates on different media.

\begin{tabular}{|c|c|c|c|c|c|}
\hline Isolates & Culture medium & Growth & Aerial mycelium & Substrate mycelium & Soluble pigment \\
\hline \multirow{4}{*}{ SCA-11 } & SCA & Good & Grey-brown & Brown & None \\
\hline & ISP-1 & Good & White-yellow & White-beige & None \\
\hline & ISP-2 & Very good & White & Brown & None \\
\hline & ISP-4 & Good & White & Beige-brown & None \\
\hline \multirow{4}{*}{ AIA-10 } & SCA & Good & Grey-Brown & Cream-light brown & None \\
\hline & ISP-1 & Good & White-yellow & White & None \\
\hline & ISP-2 & Very good & White & Cream-light brown & None \\
\hline & ISP-4 & Good & None & Brown & None \\
\hline \multirow{4}{*}{ SCA-8 } & SCA & Very good & Brown & Yellow & Light-yellow \\
\hline & ISP-1 & Good & White & White-beige & None \\
\hline & ISP-2 & Very good & Grey & Cream-light brown & Light-yellow \\
\hline & ISP-4 & Good & None & Brown & None \\
\hline \multirow{4}{*}{ SCA-5 } & SCA & Good & Grey-brown & Cream-light brown & None \\
\hline & ISP-1 & Good & White & White-beige & None \\
\hline & ISP-2 & Very good & White & Cream-light brown & None \\
\hline & ISP-4 & Good & White & Beige-brown & None \\
\hline
\end{tabular}

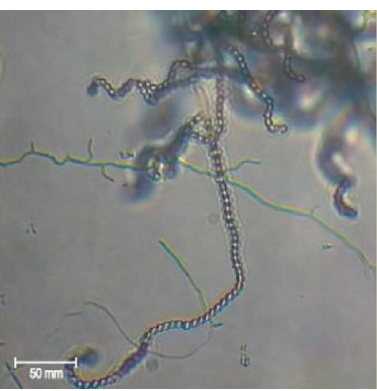

(a)

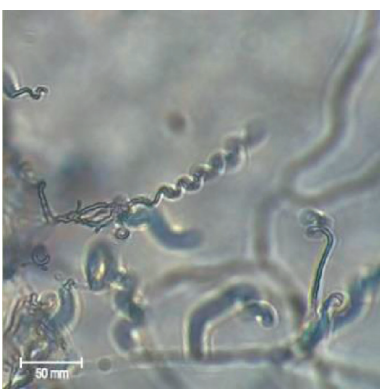

(b)

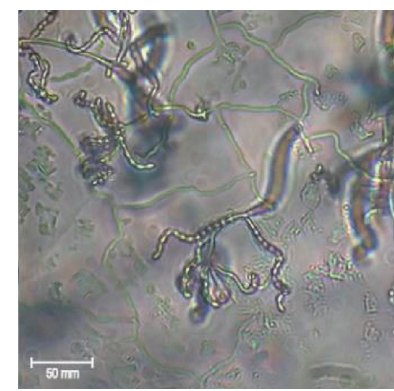

(c)

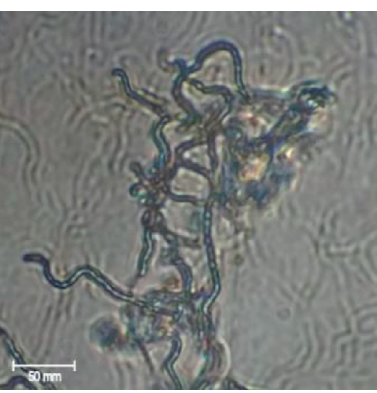

(d)

Figure 3: Microscopic morphology of selected Streptomyces examined by using a light microscope (1000×): (a) SCA-5, (b) SCA-8, (c) SCA11, and (d) AIA-10.

AIA-10, SCA-5, and SCA-8, respectively. Meanwhile at $254 \mathrm{~nm}, 6$ peaks, 8 peaks, 3 peaks, and 4 peaks were detected in the chromatogram of SCA-11, AIA-10, SCA-5, and SCA-
8 , respectively. At $276 \mathrm{~nm}$, less peaks were relatively detected, i.e., 4 peaks at SCA-11, 6 peaks at AIA-10, 3 peaks at SCA-5, and 3 peaks at SCA-8. Based on this trend, it was 
TABLE 4: Microscopy morphological, physiological, and biochemical characteristics of selected Streptomyces isolates.

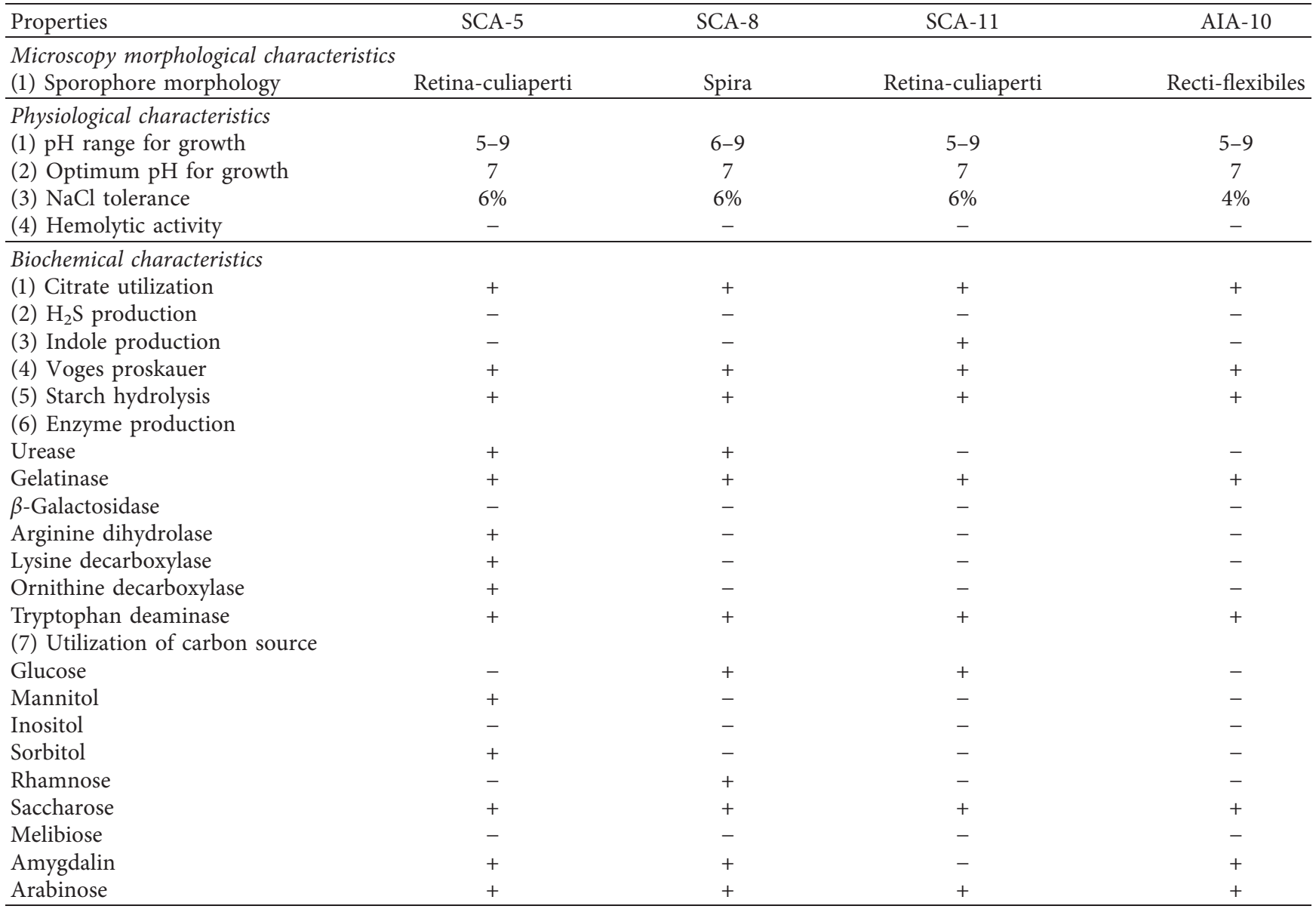

+: positive reaction, -: negative reaction.

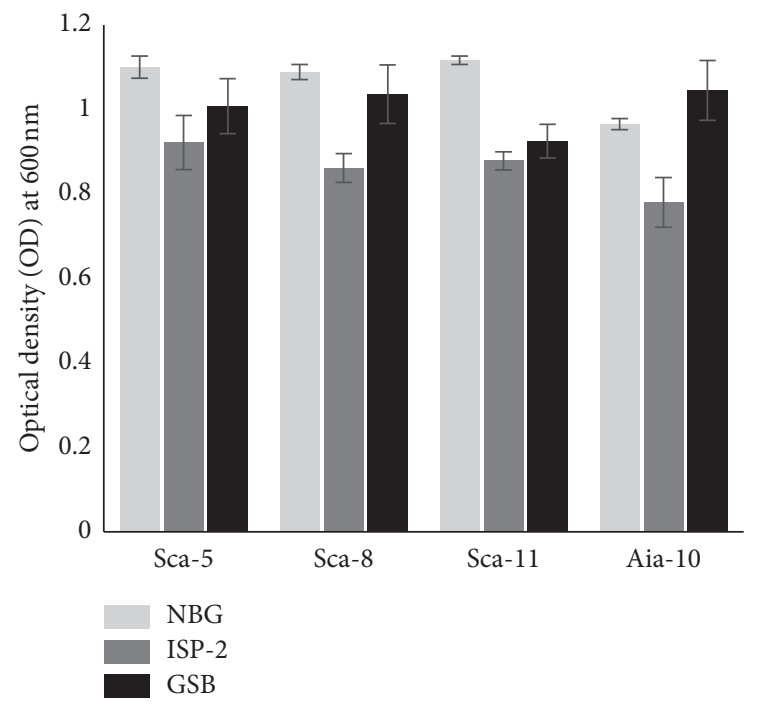

(a)

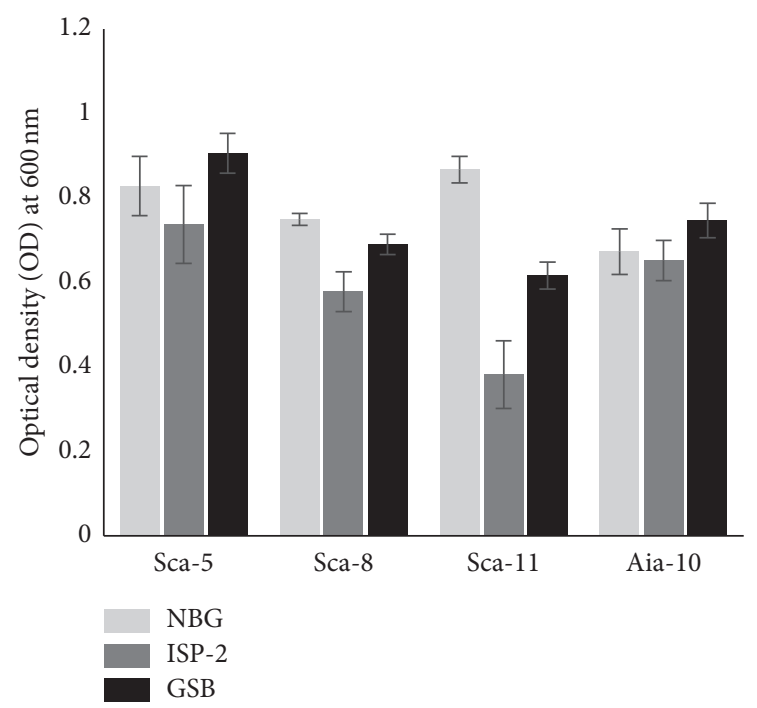

(b)

FIgUre 4: The OD values at $600 \mathrm{~nm}$ of (a) Escherichia coli and (b) Staphylococcus aureus growth exposed to the supernatant of isolates that were grown in NBG (nutrient broth glucose) broth, ISP-2 (yeast-malt extract) broth, and GSB (Gause synthetic) broth. 


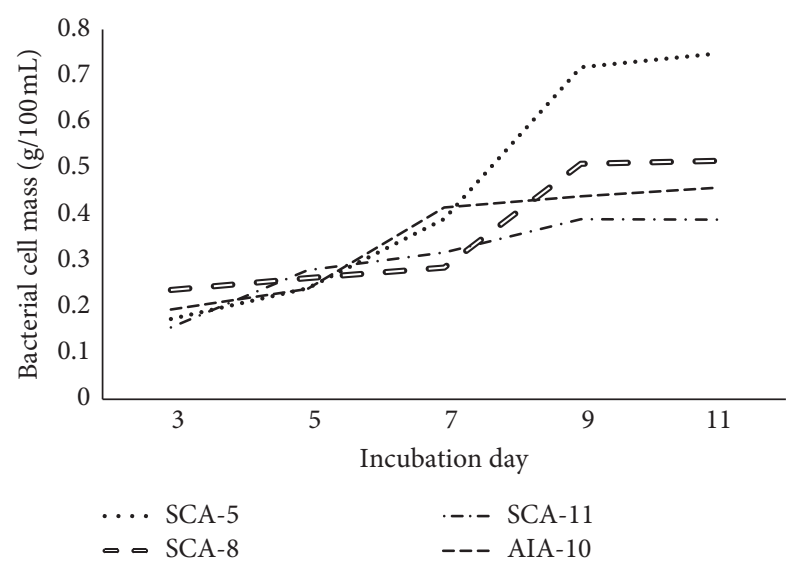

Figure 5: Growth curve of selected Streptomyces isolates on ISP-2 broth based on incubation times; mycelial pellets were harvested for growth determination by biomass measurement.

TABLe 5: Inhibition zone $(\mathrm{mm})$ of the metabolite-crude-extract $(10 \mathrm{mg} / \mathrm{mL})$ by the disc-diffusion method.

\begin{tabular}{lcccc}
\hline Crude & \multicolumn{4}{c}{ Inhibition zone $(\mathrm{mm})$} \\
extract & S. aureus & B. cereus & E. coli & P. aeruginosa \\
\hline SCA-5 & $9.7 \pm 2.38^{\mathrm{a}}$ & $9.5 \pm 1.33^{\mathrm{a}}$ & $9.0 \pm 2.69^{\mathrm{a}}$ & $8.4 \pm 0.70^{\mathrm{a}}$ \\
SCA-8 & $11.1 \pm 1.42^{\mathrm{a}}$ & $9.8 \pm 1.37^{\mathrm{b}}$ & $9.8 \pm 4.70^{\mathrm{a}}$ & $12.3 \pm 1.80^{\mathrm{b}}$ \\
SCA-11* $^{*}$ & $13.3 \pm 1.33^{\mathrm{a}}$ & $11.6 \pm 1.36^{\mathrm{b}}$ & $11.7 \pm 1.46^{\mathrm{a}}$ & $15.3 \pm 1.65^{\mathrm{c}}$ \\
AIA-10 & $22.2 \pm 3.08^{\mathrm{b}}$ & $17.8 \pm 0,46^{\mathrm{c}}$ & $18.5 \pm 0.87^{\mathrm{b}}$ & $21.3 \pm 1.63^{\mathrm{d}}$ \\
$\begin{array}{l}\text { Control } \\
(+)\end{array}$ & $23.8 \pm 0.47^{\mathrm{c}}$ & $30.7 \pm 0.07^{\mathrm{d}}$ & $22.4 \pm 0.20^{\mathrm{c}}$ & $10.4 \pm 0.17^{\mathrm{e}}$ \\
$\begin{array}{l}\text { Control } \\
(-)\end{array}$ & $0 \pm 0$ & $0 \pm 0$ & $0 \pm 0$ & $0 \pm 0$ \\
\hline
\end{tabular}

${ }^{*}$ As reported by Kurnianto et al. (25); value was mean \pm SD (standard Deviation) from three replication; Control (+): ampicillin $10 \mu \mathrm{g} / \mathrm{mL}$; Control (-): DMSO 2\%; (a, b, c, d, and e): different letters in the same column represent significance.

TABLE 6: MIC and MBC value of the metabolite-crude-extract $(10 \mathrm{mg} / \mathrm{mL})$.

\begin{tabular}{lcccccccc}
\hline \multirow{2}{*}{ Crude extract } & \multicolumn{4}{c}{ MIC $(\mathrm{mg} / \mathrm{mL})$} & \multicolumn{4}{c}{$\mathrm{MBC}(\mathrm{mg} / \mathrm{mL})$} \\
& SA & BC & EC & PA & SA & BC & EC & PA \\
\hline SCA-5 & 5 & 5 & 5 & 10 & 10 & 10 & 10 & 10 \\
SCA-8 & 10 & 10 & 10 & 10 & 10 & 10 & 10 & 10 \\
SCA-11 & 2.5 & 2.5 & 2.5 & 2.5 & 5 & 5 & 5 & 5 \\
AIA-10 & 2.5 & 2.5 & 2.5 & 2.5 & 5 & 5 & 5 & 5 \\
Control (+) & 0.035 & 0.035 & 0.07 & 0.62 & 0.07 & 0.07 & 0.15 & 1.25 \\
Control (-) & - & - & - & - & - & - & - & - \\
\hline
\end{tabular}

(-): no activity; Control (+): ampicillin; Control (-): DMSO 2\%; SA: S. aureus; BC: B. cereus; EC: E. coli; PA: P. aeruginosa.

known that at 210 and $214 \mathrm{~nm}$ were optimal absorption occurred, in which all metabolite-crude-extracts exhibited more peak numbers with more intensive areas, especially isolate SCA-11 and AIA-10. Furthermore, peaks with intensive areas were mostly detected at the beginning and the middle of the chromatogram or in the retention time between 0-5 min, 6-9 min, and 11-20 min. Meanwhile, at 254 and $276 \mathrm{~nm}$, the majority of peaks were detected in the initial
5 min retention time with smaller areas. Specifically, metabolites-crude-extract SCA-11 and AIA-10 exhibited identical peaks with different intensities at a retention time of 7.189 minutes (Figure 6).

\section{Discussion}

Four of 18 isolates with the highest antibacterial activity had been selected and characterized. Three isolates were confirmed as S. variabilis and one isolate as S. labedae. Dholakiya et al. [14] reported that $S$. variabilis $\mathrm{RD}-5$ formed white and brown-white aerial and substrate mycelium characteristics and produced yellowish pigments. Meanwhile, Mangamuri et al. [42] reported that S. labedae VSM-6 formed greyish-white and brown aerial and mycelium substrate characteristics and produced a spiral type spore chain. Furthermore, phylogenetic tree construction and alignment carried out of all nucleotide sequences in this study show that three of four isolates occupied phylogenetic positions separated from their closest group and showed homology values of less than $98 \%$. These results indicated the possibility of the three isolates to belong in a different species or considered as new species. Zhi et al. [43] stated that the percentage of homology with closest relatives was less than $98 \%$, indicating the possibility of different species. Hagstrom et al. [44] also stated that the isolate with the sequence homology percentage $\geq 97 \%$ can represent identical species, the sequence homology percentage between 93 and $97 \%$ indicated the same identity at the genus level, but differ at the species level, and the homology percentage $<93 \%$ indicated novelty at the genus level. However, claims regarding this matter must be further confirmed to validate the precise taxonomic position.

Carbon and nitrogen sources in the medium likely affected the antibacterial production [45]. The determination of media for antibacterial production showed that ISP-2 broth was the best medium. ISP-2 broth contained glucose as a simple carbon source and malt and yeast extract as organic nitrogen sources which can increase the ability of growth, pigment production, and the production of antibacterial agents [46, 47]. Al Farraj et al. [48] reported that the level of $0.55 \%$ glucose and $0.835 \%$ yeast extract in the production medium was the optimum level of bioactive metabolites production with maximum antibacterial activity Streptomyces sp. AS4. Another study by Abdelghani [49] also reported that malt extract concentration of $1.0 \%(\mathrm{w} / \mathrm{v})$ showed maximum antibacterial yield in S. albovinaceus. A study of cell biomass and antibacterial activity of all isolates showed a positive correlation, which was the optimum antibacterial activity found in the incubation period of days 9 to 11 or when the growth reached the stationary phase (maximum cell biomass). Previous studies reported that the antibacterial activity of $S$. variabilis $\mathrm{RD}-5$ increased with increasing cell growth. S. variabilis $\mathrm{RD}-5$ showed optimum antibacterial activity on days 7 and 8 or at the end of the second (stationary) growth phase [14]. According to Singh et al. [33], maximum antimicrobial activity was achieved after reaching the maximum value of biomass. 

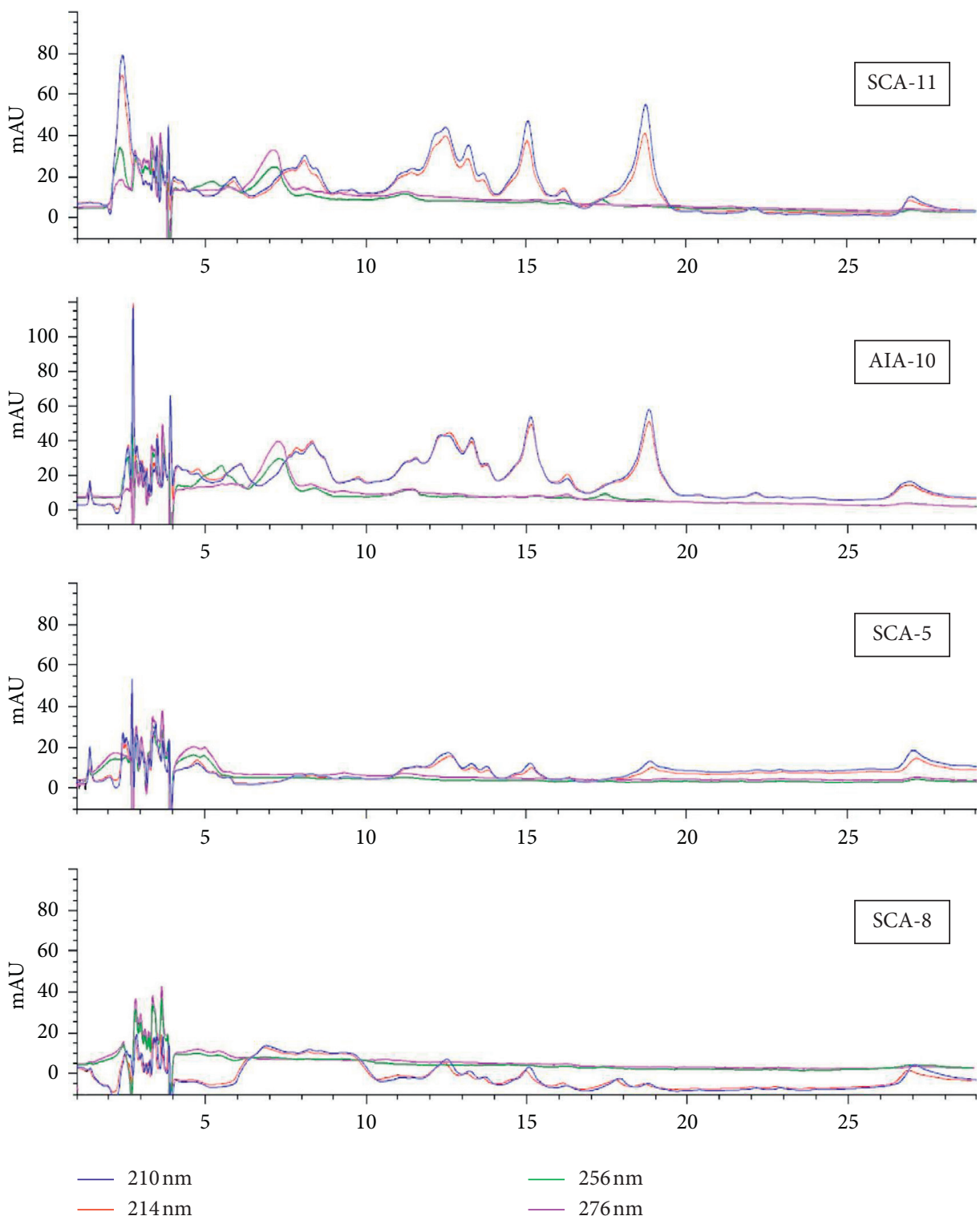

FIgURE 6: HPLC metabolite-crude-extract profile from four Streptomyces isolates detected at 210, 214, 254, and $276 \mathrm{~nm}$.

The metabolite-crude-extract from all isolates was tested and showed broad-spectrum antibacterial activity with the highest inhibitory zone and MIC and MBC values shown by AIA-10 crude extracts on $S$. aureus and $P$. aeruginosa. Actinobacteria isolates from fish gut digesta showed a result similar to that in the previous study, i.e., their crude extracts demonstrated broad-spectrum antibacterial activity against E. coli, S. aureus, B. subtilis, B. cereus, Streptococcus agalactiae, and $V$. mimicus $[25,50,51]$. Further identification of the metabolite-crude-extract found sebastenoic acid as the active component responsible for antibacterial activity with MIC values ranging from 10.0 to $110.6 \mu \mathrm{g} / \mathrm{mL}$ [51]. The difference in antibacterial activity between the test bacteria was likely due to differences in the structure and composition of the test bacteria's cell wall. In Gram-positive, peptidoglycan polymers are very close to the cell surface, allowing antibacterial compounds to penetrate cells easily.
This is different from Gram-negative because it has an outer membrane consisting of lipopolysaccharides, which act as a barrier to hydrophobic and hydrophilic compounds with certain molecular weights [52]. According to Choi and Lee [53], several types of antibacterial, which are hydrophilic with a small molecular weight $(<600 \mathrm{Da})$, can penetrate the outer membrane by diffusing through aqueous channels formed by proteins called porins. Based on this review, it was suspected that the active component with antibacterial properties contained in crude extracts had a molecular weight of less than $600 \mathrm{Da}$.

The study reported that the profiles of all metabolite extracts at the absorption band $210 \mathrm{~nm}$ were best describing the metabolites. The absorption band's range suggested the presence of amido-chromophoric groups containing one or more peptide bonds in their molecules [54, 55]. Strong absorption of this absorption range was likely due to the 
presence of the amido-chromophoric groups in the compound led to the $\pi \longrightarrow \pi^{*}$ or $n \longrightarrow \pi^{*}$ excitation of electrons [55]. Specifically, in AIA-10 and SCA-11, it was also thought to have an aromatic moiety on its molecule structure because a typical peak was detected at 254 and $276 \mathrm{~nm}[54,56]$. A similar study reported by Ezra et al. [54] obtained peaks at 208 and $214 \mathrm{~nm}$ and a broad band at 270 on the coronamycin antimicrobial peptide. Further analysis identified that the peaks found between 208 and $214 \mathrm{~nm}$ were composed of threonine, alfa-aminobutyric acid, methionine, and leucine residues, while the $270 \mathrm{~nm}$ broad band was corresponded to tyrosine residue [54]. The crude extract profile also showed that SCA-11 and AIA-10 likely exhibited higher hydrophobicity properties than the other two extracts, as shown by the presence of peak with an intensive area at the retention period of 11-20 min. These properties reported could increase antibacterial activity through hydrophobic interaction of antibacterial compounds in the form of insertion into cell membranes and, then, disrupt intracellular bacteria $[57,58]$. However, other factors such as charge, size, sequence, and structure of the compound also influenced the antimicrobial properties [59]. Purifying of the metabolitecrude-extract, therefore, had been subjected for further study to identify and confirm the factors responsible for these biological activities.

\section{Conclusions}

The four isolates from the gut of estuarine fish Chanos chanos which were identified as Streptomyces showed potential inhibitory activity against test bacteria on preliminary screening. Production with optimum medium ISP-2 broth, extraction, and antibacterial activity test on the metabolitecrude-extract showed that all isolates had broad-spectrum antibacterial activity against $S$. aureus, B. cereus, $P$. aeruginosa, and E. coli. Compounds suspected to be peptide in a metabolite-crude-extract are thought to be responsible for antibacterial activity. These results indicate that Streptomyces isolated from new environmental niches produce potential bioactive compounds and facilitate the discovery of new antibacterial agents.

\section{Data Availability}

All datasets generated or analyzed during this study are available upon reasonable request from the corresponding author

\section{Conflicts of Interest}

The authors declare that there are no conflicts of interest regarding the publication of this paper.

\section{Acknowledgments}

The authors acknowledge the Ministry of Research, Technology and Higher Education of the Republic of Indonesia for funding this research under contract no. 4418/IT3.11/ $\mathrm{PN} / 2018$.

\section{References}

[1] P. Sivalingam, K. Hong, J. Pote, and K. Prabakar, "Extreme environment Streptomyces: potential sources for new antibacterial and anticancer drug leads?" International Journal of Microbiology, vol. 2019, pp. 1-20, 2019.

[2] M. Kaltenpoth, "Actinobacteria as mutualists: general healthcare for insects?” Trends in Microbiology, vol. 17, no. 12, pp. 529-535, 2019.

[3] R. F. Seipke, M. Kaltenpoth, and M. I. Hutchings, "Streptomycesas symbionts: an emerging and widespread theme?" FEMS Microbiology Reviews, vol. 36, no. 4, pp. 862-876, 2012.

[4] G. Lewin, C. Carlon, M. G Chevrette et al., "Evolution and ecology of actinobacteria and their bioenergy applications," Annual Review of Microbiology, vol. 70, no. 1, pp. 235-254, 2017.

[5] L. V. Flórez, P. H. W. Biedermann, T. Engl, and M. Kaltenpoth, "Defensive symbioses of animals with prokaryotic and eukaryotic microorganisms," Natural Product Reports, vol. 32, no. 7, pp. 904-936, 2015.

[6] N. A. Moran, "Symbiosis as an adaptive process and source of phenotypic complexity," Light Evolution, vol. 1, pp. 165-181, 2007.

[7] M. G. Chevrette, C. M. Carlson, H. E. Ortega et al., "The antimicrobial potential of Streptomyces from insect microbiomes," Nature Communications, vol. 10, no. 1, pp. 1-11, 2019.

[8] A. J. Book, G. R. Lewin, B. R McDonald et al., "Evolution of high cellulolytic activity in symbiotic Streptomyces through selection of expanded gene content and coordinated gene expression," PLoS Biology, vol. 14, no. 6, pp. 1-21, 2016.

[9] N. C. James, P. D. Cowley, A. K. Whitfield, and S. J. Lamberth, "Fish communities in temporarily open/closed estuaries from the warm- and cool-temperate regions of South Africa: a review," Reviews in Fish Biology and Fisheries, vol. 17, no. 4, pp. 565-580, 2007.

[10] M. Nett, H. Ikeda, and B. S. Moore, "Genomic basis for natural product biosynthetic diversity in the actinomycetes," Natural Product Reports, vol. 26, no. 11, pp. 1362-1384, 2009.

[11] P. M and A. B, "16S RRNA gene characterization of the actinomycete-streptomyces tuirus, from the estuary region of ariyankuppam, puducherry- union territory, India," International Journal of Pharma and Bio Sciences, vol. 7, no. 4, pp. B816-B821, 2016.

[12] M. S. Hossain, N. Gopal Das, S. Sarker, and M. Z. Rahaman, "Fish diversity and habitat relationship with environmental variables at Meghna river estuary, Bangladesh," The Egyptian Journal of Aquatic Research, vol. 38, no. 3, pp. 213-226, 2012.

[13] S. Sengupta, A. Pramanik, A. Ghosh, and M. Bhattacharyya, "Antimicrobial activities of actinomycetes isolated from unexplored regions of Sundarbans mangrove ecosystem," BMC Microbiology, vol. 15, p. 1, 2015.

[14] R. N. Dholakiya, R. Kumar, A. Mishra, K. H. Mody, and B. Jha, "Antibacterial and antioxidant activities of novel actinobacteria strain isolated from Gulf of Khambhat, Gujarat," Frontiers in Microbiology, vol. 8, pp. 1-16, 2017.

[15] R. E. de Lima Procópio, I. R. da Silva, M. K. Martins, J. L. de Azevedo, and J. M. de Araújo, "Antibiotics produced by streptomyces," The Brazilian Journal of Infectious Diseases, vol. 16, no. 5, pp. 466-471, 2012.

[16] S. Tan, G. Moore, and J. Nodwell, "Put a bow on it: knotted antibiotics take center stage," Antibiotics, vol. 8, no. 3, 2019.

[17] P. G. Arnison, M. J. Bibb, G Bierbaum et al., "Ribosomally synthesized and post-translationally modified peptide natural 
products: overview and recommendations for a universal nomenclature," Natural Product Reports, vol. 30, no. 1, pp. 108-160, 2014.

[18] K. L. Constantine, M. S. Friedrichs, D Detlefsen et al., "Highresolution solution structure of siamycin II: novel amphipathic character of a 21-residue peptide that inhibits HIV fusion," Journal of Biomolecular NMR, vol. 5, no. 3, pp. 271-286, 1995.

[19] A. Ökesli, L. E. Cooper, E. J. Fogle, and W. A. Van Der Donk, "Nine post-translational modifications during the biosynthesis of cinnamycin," Journal of the American Chemical Society, vol. 133, no. 34, pp. 13753-13760, 2011.

[20] L. Huo, S. Rachid, M. Stadler, S. C. Wenzel, and R. Müller, "Synthetic biotechnology to study and engineer ribosomal bottromycin biosynthesis," Chemistry \& Biology, vol. 19, no. 10, pp. 1278-1287, 2012.

[21] M. H. Farris, C. Duffy, R. H. Findlay, and J. B. Olson, "Streptomyces scopuliridis sp. nov., a bacteriocin-producing soil streptomycete," International Journal of Systematic and Evolutionary Microbiology, vol. 61, no. 9, pp. 2112-2116, 2011.

[22] J. Claesen and M. J. Bibb, "Biosynthesis and regulation of grisemycin, a new member of the linaridin family of ribosomally synthesized peptides produced by Streptomyces griseus IFO 13350," Journal of Bacteriology, vol. 193, no. 10, pp. 2510-2516, 2011.

[23] K. Amagai, H. Ikeda, J Hashimoto et al., "Identification of a gene cluster for telomestatin biosynthesis and heterologous expression using a specific promoter in a clean host," Science Reports, vol. 7, no. 1, pp. 2-4, 2017.

[24] I. Kaweewan, M. Ohnishi-Kameyama, and S. Kodani, "Isolation of a new antibacterial peptide achromosin from Streptomyces achromogenes subsp. achromogenes based on genome mining," The Journal of Antibiotics, vol. 70, no. 2, pp. 208-211, 2017.

[25] M. A. Kurnianto, H. D. Kusumaningrum, and H. N. Lioe, "Penapisan actinobacteria akuatik penghasil antibakteri Dari ikan bandeng (chanos chanos) dan belanak (Mugil cephalus) dengan metode double-layer diffusion," Jurnal Pascapanen Dan Bioteknologi Kelautan Dan Perikanan, vol. 15, no. 1, pp. 1-11, 2020.

[26] G. Gebreyohannes, F. Moges, S. Sahile, and N. Raja, "Isolation and characterization of potential antibiotic producing actinomycetes from water and sediments of Lake Tana, Ethiopia," Asian Pacific Journal of Tropical Biomedicine, vol. 3, no. 6, pp. 426-435, 2013.

[27] Q. Li, X. Chen, Y. Jiang, and C. Jiang, "Morphological identification of actinobacteria," "Morphological identification of actinobacteria," in Actinobacteria-basics and Biotechnological Applications, d Dharumadurai, Ed., p. 388, IntechOpen, London, UK, 2015.

[28] D. G. Pitcher, N. A. Saunders, and R. J. Owen, "Rapid extraction of bacterial genomic DNA with guanidium thiocyanate," Letters in Applied Microbiology, vol. 8, no. 4, pp. 151-156, 1989.

[29] A. Hiraishi, Y. Kamagata, and K. Nakamura, "Polymerase chain reaction amplification and restriction fragment length polymorphism analysis of 16s RRNA genes from methanogens," Journal of Fermentation and Bioengineering, vol. 79, no. 6, pp. 523-529, 1995.

[30] D. G. S. Andayani, U. Sukandar, E. Y. Sukandar, and I. K. Adnyana, "Antibacterial, antifungal and anticancer activity of five strains of soil microorganisms isolated from tangkuban perahu mountain by fermentation," Hayati Journal of Biosciences, vol. 22, no. 4, pp. 186-190, 2015.
[31] E. B. Shirling and D. Gottlieb, "Methods for characterization of Streptomyces species," International Journal of Systematic Bacteriology, vol. 16, no. 3, pp. 313-340, 1966.

[32] T. G. Pridham and D. Gottlieb, "The utilization of carbon compounds by some actinomycetales as an aid for species determination," Journal of Bacteriology, vol. 56, no. 1, pp. 107-114, 1948.

[33] L. S. Singh, H. Sharma, and N. C. Talukdar, "Production of potent antimicrobial agent by actinomycete, Streptomyces sannanensis strain SU118 isolated from phoomdi in Loktak Lake of Manipur, India," BMC Microbiology, vol. 278, pp. 113, 2014.

[34] M. G. Bernal, ÁI. Campa-Córdova, P. E. Saucedo, and M. C. González, "Isolation and in vitro selection of actinomycetes strains as potential probiotics for aquaculture," Veterinary World, vol. 8, no. 2, pp. 170-176, 2015.

[35] A. Nurkanto and A. Agusta, "Identifikasi molekular dan karakterisasi morfo-fisiologi actinomycetes penghasil senyawa antimikroba (Molecular identification and morphophysiological characterization of actinomycetes with antimicrobial properties)," Indonesian Journal of Biotechnology, vol. 11, no. 2, pp. 195-203, 2015.

[36] S. Azimi, M. Basei Salehi, and N. Bahador, "Isolation and identification of Streptomyces ramulosus from soil and determination of antimicrobial property of its pigment," Modern Medical Laboratory Journal, vol. 1, no. 1, pp. 36-41, 2017.

[37] M. Memarpoor-Yazdi, A. Asoodeh, and J. Chamani, "A novel antioxidant and antimicrobial peptide from hen egg white lysozyme hydrolysates," Journal of Functional Foods, vol. 4, no. 1, pp. 278-286, 2012.

[38] Zothanpuia, A. K. Passari, P Chandra et al., "Production of potent antimicrobial compounds from Streptomyces cyaneofuscatus associated with fresh water sediment," Frontiers in Microbiology, vol. 8, pp. 1-13, 2017.

[39] M. Balouiri, M. Sadiki, and S. K. Ibnsouda, "Methods for in vitro evaluating antimicrobial activity: a review," Journal of Pharmaceutical Analysis, vol. 6, no. 2, pp. 71-79, 2016.

[40] A. M. Shah, Shakeel-u-Rehman, A. Hussain et al., "Antimicrobial investigation of selected soil actinomycetes isolated from unexplored regions of Kashmir Himalayas, India," Microbial Pathogenesis, vol. 110, pp. 93-99, 2017.

[41] I. Djinni, A. Defant, M. Kecha, and I. Mancini, "Metabolite profile of marine-derived endophyticStreptomyces sundarbansensis WR1L1S8by liquid chromatography-mass spectrometry and evaluation of culture conditions on antibacterial activity and mycelial growth," Journal of Applied Microbiology, vol. 116, no. 1, pp. 39-50, 2014.

[42] U. K. Mangamuri, V. Muvva, S. Poda, and S. Kamma, "Isolation, identification and molecular characterization of rare actinomycetes from mangrove ecosystem of Nizampatnam," Malaysian Journal of Microbiology, vol. 8, no. 2, pp. 83-91, 2012.

[43] X.-Y. Zhi, W.-J. Li, and E. Stackebrandt, "An update of the structure and 16S rRNA gene sequence-based definition of higher ranks of the class Actinobacteria, with the proposal of two new suborders and four new families and emended descriptions of the existing higher taxa," International Journal of Systematic and Evolutionary Microbiology, vol. 59, no. 3, pp. 589-608, 2009.

[44] А. Hagström, J. Pinhassi, and U. Zweifel, "Biogeographical diversity among marine bacterioplankton," Aquatic Microbial Ecology, vol. 21, no. 3, pp. 231-244, 2000. 
[45] C. Vilches, C. Mendez, C. Hardisson, and J. A. Salas, "Biosynthesis of oleandomycin by Streptomyces antibioticus: influence of nutritional conditions and development of resistance," Journal of General Microbiology, vol. 136, no. 8, pp. 1447-1454, 1990.

[46] A. M. Calvo, R. A. Wilson, J. W. Bok, and N. P. Keller, "Relationship between secondary metabolism and fungal development," Microbiology and Molecular Biology Reviews, vol. 66, no. 3, pp. 447-459, 2002.

[47] R. Manikkam, G. Venugopal, B. Ramasamy, and V. Kumar, "Effect of critical medium components and culture conditions on antitubercular pigment production from novel Streptomyces sp D25 isolated from Thar desert, Rajasthan," Journal of Applied Pharmaceutical Sciences, vol. 5, no. 6, pp. 15-19, 2015.

[48] D. A. Al Farraj, R. Varghese, C. Vágvölgyi, M. Soliman Elshikh, A. M. Alokda, and A. Hossam Mahmoud, "Antibiotics production in optimized culture condition using low cost substrates from Streptomyces sp. AS4 isolated from mangrove soil sediment," Journal of King Saud University Science, vol. 32, no. 2, pp. 1528-1535, 2020.

[49] T. Abdelghani, "Production of antibacterial and antifungal metabolites by S.albovinaceus strain no.10/2 and media optimization," International Journal of Biological Macromolecules, vol. 3, no. 10, pp. 197-203, 2017.

[50] M. Jami, M. Ghanbari, W. Kneifel, and K. J. Domig, Phylogenetic diversity and biological activity of culturable Actinobacteria isolated from freshwater fish gut microbiota," Microbiological Research, vol. 175, pp. 6-15, 2015.

[51] L. M. Sanchez, W. R. Wong, R. M. Riener, C. J. Schulze, and R. G. Linington, "Examining the fish microbiome: vertebratederived bacteria as an environmental niche for the discovery of unique marine natural products," PLoS One, vol. 7, no. 5, p. e35398, 2012.

[52] G. M. S. Soares, L. C. Figueiredo, M. Faveri, S. C. Cortelli, P. M. Duarte, and M. Feres, "Mechanisms of action of systemic antibiotics used in periodontal treatment and mechanisms of bacterial resistance to these drugs," Journal of Applied Oral Science, vol. 20, no. 3, pp. 295-309, 2012.

[53] U. Choi and C.-R. Lee, "Antimicrobial agents that inhibit the outer membrane assembly machines of gram-negative bacteria," Journal of Microbiology and Biotechnology, vol. 29, no. 1, pp. 1-10, 2019.

[54] D. Ezra, U. F. Castillo, G. A. Strobel et al., "Coronamycins, peptide antibiotics produced by a verticillate Streptomyces sp. (MSU-2110) endophytic on Monstera sp," Microbiology, vol. 150, no. 4, pp. 785-793, 2004.

[55] V. Praveen and C. K. M. Tripathi, "Studies on the production of actinomycin-D byStreptomyces griseoruber- a novel source," Letters in Applied Microbiology, vol. 49, no. 4, pp. 450-455, 2009.

[56] M. Taniguchi and J. S. Lindsey, "Database of absorption and fluorescence spectra of $>300$ common compounds for use in photochemcad," Photochemistry and Photobiology, vol. 94, no. 2, pp. 290-327, 2018.

[57] M. Dathe and T. Wieprecht, "Structural features of helical antimicrobial peptides: their potential to modulate activity on model membranes and biological cells," Biochimica et Biophysica Acta (BBA)-Biomembranes, vol. 1462, no. 1-2, pp. 71-87, 1999.

[58] N. Naarmann, B. Bilgiçer, H. Meng, K. Kumar, and C. Steinem, "Fluorinated interfaces drive self-association of transmembrane $\alpha$ helices in lipid bilayers," Angewandte Chemie International Edition, vol. 45, no. 16, pp. 2588-2591, 2006.
[59] Y. Chen, M. T. Guarnieri, A. I. Vasil, M. L. Vasil, C. T. Mant, and R. S. Hodges, "Role of peptide hydrophobicity in the mechanism of action of $\alpha$-helical antimicrobial peptides," Antimicrobial Agents and Chemotherapy, vol. 51, no. 4, pp. 1398-1406, 2007. 